\title{
A Review of Flood Risk Assessment
}

\author{
${ }^{*}$ Karamat Ali ${ }^{1,2}$, Roshan M. Bajracharya ${ }^{1}$, Hriday Lal. Koirala ${ }^{3}$ \\ ${ }^{1}$ Department of Environmental Sciences and Engineering and Aquatic Ecology Center, Kathmandu University, Nepal \\ ${ }^{2}$ Department of Environmental Sciences, Karakoram International University, Gilgit, Pakistan \\ ${ }^{3}$ Central Department of Geography, Tribhuvan University, Kirtipur, Nepal
}

\begin{abstract}
Floods are one of the most common hazards in the world and cause loss of lives, livelihood and property destruction. The objective of this study was to review and synthesize concepts and techniques of flood hazard, vulnerability and risk assessment with reference to the Himalayan region. Flood risk is a function and a product of hazard and vulnerability. The impact of flood and flash flood (slow onset and rapid onset) events at a particular sitecan reflect key socioeconomic factors and environmental services, like number of people at risk, affect on ecological services and capability of human population for recovery. Risk assessment is important in making decisions, policies and managing floods. Using PRISMA methodology of literature review, 120 articles were retrieved using PubMed and Google Scholar database. 90 articles were included in the initial review. 30 articles were excluded from the review after reading the whole content because they did not match the objectives of the literature review and the inclusion criteria. Flood hazard assessment techniques are based on various parameters such as meteorological, hydrological and socioeconomic. There are four important steps in flood risk assessment such as characterizing the area, determining hazard level and intensity, assessing vulnerability and risk. Recently, advancement in GIS, remote sensing and hydraulic modeling technology has been extensively used in formulating models used for flood hazard calculation and risk analysis. The occurrence of floods in mountainous regions are now more common related to past and in the future, itseems more frequent due to global warming. Community based flood warning systems can go a long way in helping rural communities, as well as flood management agencies, to prepare for flash floods. The enhancement of community resilience through socioeconomic empowerment and strengthened adaptive capacity can play a vital role in flood disaster management.
\end{abstract}

Keywords- flood, hazard, vulnerability, risk, GIS, global warming, disaster.

\section{INTRODUCTION}

The etymology of the term "Hazard" probably began from the French language which meant "put something at stake in a game of change played with dice" in 1300 A.D. In English, the word hazard was first referred in 1540s as "Chance of loss or harm, risk" (Ghimire, 2010; Sharma, 2013). In the beginning the term 'hazard' was understood as 'natural hazards' which was defined as those elements of the physical environment, harmful to man and caused by forces extraneous to him (Burton et al., 1978). UNDRO (1983) defined it as the probability of occurrence, within a specific period of time in a given area, which is potentially damaging phenomenon. The term hazard in a wider sense, as a threat and future source of danger, which has potential to cause harm to people, human activity, property and loss of environmental amenities (ADPC, 2015). UNISDR (2009) defines a hazard as a dangerous phenomenon, which affect human activity or livelihood, services, socioeconomic disruption and environmental damages. There are some important characteristics of a hazard such as magnitude or scale, intensity and frequency of events. A natural phenomenon which may occur in a human occupied area with the probability of causing loss or damage is called a hazard event. A physical event in a remote area that does not affect human beings is not considering a disastrous event (Bohle, 2001).

Hazard can be categorized as natural and anthropogenic hazard. Natural hazard can be classified a geophysical (earthquake, landslides, volcanic activity), hydrometeorological (floods, tropical storms, drought), and biological (disease epidemic).Anthropogenic hazard incorporates the human processes such as climate change, fire, mining of non-renewable resources, environmental degradation and technological hazards (UNISDR, 2009). The hydro-meteorological phenomenon is the process of atmospheric and hydrologic that may cause loss of life, injury or other health impacts, property damage, loss of livelihoods and services, social and economic disruption and environmental damage is called a hydro-meteorological hazard. These hazards include tropical cyclones, 
thunderstorm, hailstorm, tornados, heavy snowfall, avalanches and coastal storm surges, floods including flash floods, heat waves and drought (Balikie, et al., 1994).

Floods are the most lethal kind of hydro-meteorological disaster on the earth's surface (Ologunorisa, 2004). Flood is the most impressive interaction between man and his environment, which put emphasis on both the sheer force of natural events and man's insufficient efforts to control them (Khan and Rehman, 2005). There are several types of floods such as riverine flooding, flash flood, urban drainage, ground failures, fluctuating lake level, coastal flooding and erosion. The dynamics of riverine flooding vary with terrain. In flat areas, floods my shallow, slow-moving for days or even weeks. In hilly and mountainous area, floods may come minutes after a heavy rain. The short notice, large depths and high velocities of flash floods make these types of floods particularly dangerous. Among the common types of riverine flooding are overbanks flooding, flash floods, dam and levee failure, alluvial fans, ice jam flooding and moveable bed streams (Borga, et al., 2014). A flash flood is generally defined as a rapid onset flood of short duration with a relatively high peak discharge (WMO, 2010). A rapid and extreme flow of high water into a normally dry area, or a rapid water level rise in a stream or creek above a predetermined flood level (USNWS, 2010). IPCC (2007) studies revealed that, there is no evidence that the trend of global warming will discontinue. The implications of global warming affect future flood disasters. There are also concerns about continued growth and development in floodplains interfering with natural systems and ecological processes and highlighting that human behavior is a contributor to the problem of flooding. Encroachment in the form of unsustainable land use and rapid economic development practices may often make a sizeable contribution to increase of risk and vulnerability (Wheater and Evansb, 2009). According to Dilley et al. (2005) estimated that more than one third of the world's land area is flood prone, which affecting around 82 percent of the world population. In 90 countries, about 196 million people are exposed to catastrophic flooding and 170,000 deaths were associated with floods worldwide between 1980 and 2010 (UNDP (2004). Flooding is the most common among the all environmental hazards and it regularly claims over huge number of lives per year and adversely affects millions of the people world-wide (Smith, 1996).

Mountain regions occupy approximately one fifth of the earth's land surface and cover $54 \%$ of Asia's land mass. Mountainous regions are inhabited by 800 millions of people. The major rivers of the world originate from these areas (ICIMOD, 2002). The Seasonality of streamflow in mountainous basins has been found to be extremely sensitive to global warming and the concern about the increase of flood risk in these areas is rapidly raising (Diaz et al., 2003; Barnett et al., 2005; Bates et al., 2008; Marty, 2008).

Risk as the production of hazards such physical and statistical aspect of the flooding and vulnerability is the exposure of people and assets to floods and susceptibility of the elements at risk to suffer from flood damage (Cutter, 1996).The concept of vulnerability has been a powerful analytical tool for describing states of susceptibility to harm, powerlessness, and marginality of both physical and social system (Adger, 2006). The concept of vulnerability implies a measure of risk associated with the physical, social, and economic aspects and implications resulting from the system's ability to cope with the resulting event. The word disaster is used in diverse ways, mostly to refer to any sudden, unexpected misfortune, regardless of number of people, size of region or, country or even theentire world (Proag, 2014).

Smith and Petley (2009) analyzed that risk is a statistical concept and probability refer to a negative event or condition which effect people, infrastructure and environment. Risk an integral part of life. Risk is derived the Chinese word "Weji-Ji" combines the characters meaning opportunity/chance and danger; it always involved some balance between profit and loss (Smith, 1996). Risk referred to chance of loss of life or property, or injury, damage, or disruption to economic activity due to a particular event for a given area and reference period. Risk is the combination of hazard and vulnerability (ICIMOD, 2010). The research of flood risk is a multidisciplinary character and subject of interest for hydrologist, sociologists, economists, environmentalists and geographers (Solı́n et al., 2011; Solı́n 2012). Hazard assessment mapping delineates flood hazard areas in the river basin by local knowledge, hydro-meteorological, geomorphologic and socio-economic data can be used (Tsay, 2013; Forkuo, 2011). Geographic information system (GIS) and remote sensing provides a broad range of tools for determining area affected by floods and for forecasting areas that are likely to be flooded due to high water level in a river. Remote sensing technology along with GIS has become the key tool for flood monitoring in recent years ((Getahun and Gebre, 2015; Pradhan, et al., 2009).

The need of research in flood hazard, vulnerability and risk assessment has been stress in literature (Askew, 1999; 
Smith, 1999; Ologunorisa, 2001). The objective of this paper to review, synthesize concepts and techniques of risk assessment into a coherent piece and give an overview of recent literature related to flood hazard, vulnerability and risk.

\section{MATERIAL AND METHODS}

Using PRISMA methodology of literature review, 120 articles were retrieved using Pub med and Google Scholar database. 90 articles were included in initial review. 30 articles were excluded from the review after reading the whole content because they did not match the objectives of the literature review and the inclusion criteria. Key words used to search the articles are: Flood and floods types, flash floods, hazard and disaster, type of hazards, flood hazard assessment, flood vulnerability assessment, floods risk assessment, flood hazard mapping, GIS based flood hazard assessment, Socio-economic impacts of floods, application of remote sensing and GIS for floods hazard mapping and Disaster management, Climate change and flooding, Global warming and it impacts, floods risk in mountain areas, monsoon and floods, poverty and floods.

Scientific literatures were searched from journal articles, books, proceedings and others published article starting from the year 1995 to the year 2015 .

The major journals included in this review paper were from various journals such as, Journal of Flood Risk Assessment, Geophysical Research Letters, Journal of Water Resources Management, Natural Hazards and Earth System Sciences, Journal of Natural Hazards, Hydrology of Mountain Areas, Journal of Geography and Regional Planning, Mountain Research and Development, Indian society of Remote Sensing, Hydrological Science Journal, International Journal of Geomantics and Geosciences, Arabian Journal of Geosciences, Global Environmental Change, International Journal of Disaster Prevention and Management, ICIMOD Archive, Journal of Risk Analysis. Though the articles published in the last 20 years were the prime concern initially but data from a few older articles were also extracted in order to give meaning to the paper.

\section{RESULTS AND DISCUSSION}

\section{Theoretical Clarification}

Flood hazard, vulnerability and risk assessment requires an understanding of the causes of a potential disaster. According to Ken Granger (2002) and UNCHS-HABITAT (1981) has defined the term hazard, vulnerability, element at risk and risk are in the following way:
Hazard (H) means the probability of occurrence, within a specified period of time in a given area and potentially damaging natural phenomenon.

Vulnerability (V) means the degree of loss to a given element at risk or set of such elements resulting from the occurrence of a natural phenomenon of a given magnitude.

Element at risk (E) mean the population, building and civil engineering works, economic activities, public services, utilities and infrastructure in a given area.

Risk (R) means the expected degree of loss due to a particular natural phenomenon. Risk analysis can be defined as a systematic use of available information to determine how often specified events may occur and the magnitude of their likely consequences.

Flood risk is a function and a product of hazard and vulnerability, "Risk $=$ Hazard $x$ Vulnerability" (Ologunorisa, 2001).

\section{Risk Assessment Techniques}

Meteorological Parameters

Meteorologically flood can be defined as situation over a region or place where that rainfall is mostly heavy and higher than the normal climatologically mean value. The definition and criteria for flood is vary in different realms such as in South Asia, when seasonal rainfall is an excess over a normal meteorological subdivision is regarded as moderated, and an extremely excessive rainfall over the normal mean value as a sever flood. (Parthasarathy, et al., 1987; Ologunorisa, 2001). There is combination of factors contribute to the severe flood such as heavy winter snowfall, high summer temperature, development of unusual low pressure, change in direction of track and anomaly of rainfall. This severe weather can be explained in terms of climate change, but from individualevent, climate change cannot be confirmed until supported by long-time meteorologicaldata(Atta-ur-Rahman, 2010; Atta-urRahman, 2003). The total seasonal rainfall of June through September as well as it time developed an index that has been evolved for identifying a year as hydrological flood/drought in different parts of Indian, Pakistan and Bangladesh (Mirza, 2003; Ologunorisa, 2004).

The quality of weather forecasting models has significantly improved during the last years. These models can provide important information on temperature, wind, and precipitation for forecasting of any meteorological event. Forecasting cannot assess accurately the location and the extent of precipitation. In particular, information on the location and intensity of local convective heavy rainfall is still insufficient for the direct forecast of flash floods (Koutsoyiannis, 2009). A coherent global climatology of 
flooding cannotbe easily constructed from stream discharge frequency and magnitude statistics. The difficultly arises because the frequency and magnitude of floods vary between and within drainage networks because of variability in basin characteristics. This kind of variability is complicated due to diversity in weather systems (Hayden, 1988).

Hydrological parameters

Hydrologic response of the basins as represented by the available stream gauge network is a result of the physical response of several of the physiographic regions contained within the basins (Smakhtin, 2001). Hydrological variables are very important to monitor flood risk. For such an assessment it is necessary to analyze the change in hydrological conditions and especially the characteristics of heavy precipitation, at the regional to local hydrological scale. Hydro-climatologically parameters are essential for understanding the interaction between the atmosphere and hydrosphere (Smakhtin, et al., 2001).

The hydrological records and analysis of the flood wave has been used to improve manipulation with waters using weirs, flood diversion canals and retentions. This hydrological analysis highlighting particularly to prevent disastrous floods in different parts of world.Flooding from rain -onsnow events are most damaging floods in rivers and these large floods inundate communities and farms lands (Trinic, 1997;Kattelmann, 1997). The analysis of previous floods, volumes, duration, and the assessment of damages and the evaluation of possible changes in the flood behavior are particularly useful for the flood hazard management. An assessment of the change in floods severity and intensity can be analyzed at much smaller scales than the global or continental level.

Socio-Economic Vulnerability

Socio-economic vulnerability refers to a common set of indicators to explore differences in social and economic vulnerability between places. Vulnerability has frequently been characterized as a function of both a system's exposure and sensitivity to stress and its capacity to absorb or cope with effects of these stressors (Gunderson and Holling, 2001). The concept of vulnerability has been a powerful analytical tool for describing states of susceptibility to harm, powerlessness, and marginality of both physical and social systems, and for guiding normative analysis of actions to enhance well-being through reduction of risk (Janssen, et al., 2006). A vulnerability measure focused on human well-being therefore incorporates material aspects and outcomes of vulnerability (Adger and Winkels, 2006).
The ability of a society in a physically vulnerable zone to acclimatize to flash flood or disaster risk determines socioeconomic vulnerability.Adaptive capacity of a people itself is a function of social andeconomic development. Due to increase in population, poverty, limited availability of land, communities develop new settlements along river banks or flash flood debris fan, which indicates a good example of high vulnerable to flash floods. As compare to those communities with good access to communication, financial institutions, markets and diversified income sources have stronger adaptive capacity and are hence, less vulnerable (ICIMOD, 2007; ICIMOD, 2008; Birkmann, 2007). Chen (2010) and Tung (2011) describes that assessing socio-economic vulnerability determines how factors of population distribution, agricultural activities, industry, and infrastructure influence the process of assessing flooding vulnerability, simulate flooding situations under different rainfall scenarios and implementation of land use and coping strategies for planning flood-prone areas.

Physical vulnerability relates to buildings, infrastructure and agriculture. Although the focus is on physical assets, it also includes the potential loss of crops and other infrastructure necessary to livelihood. Vulnerability analysis should examine the risk faced by critical facilities, which are vital to the functioning of societies in disaster situations, such as hospitals and dispensaries, emergency services, transport, communication systems, essential services (Rose, 2007). Social vulnerable groups include women, mentally and physically handicapped persons, children, and elderly persons, the poor people, refugees, and livestock. Economic vulnerability assesses the risk of hazard-causing losses to economic assets and processes. These falls into two groups: Direct damages to physical and social infrastructures, repair or replacement cost and crop damage while indirect losses refers to loss in production, employment, vital services, income disparities (Cutter, et al., 2001). There is also increase in the incidence of psychiatric disorders in the flood affected population; some common problems are acute stress disorder, post-traumatic stress disorder, anxiety disorders, depression and alcohol and drug abuse (Ali, et al., 2015). The Environmental components includes indicators which refer to damage to the environment caused by flood events or manmade interferences which could increase the vulnerability of certain areas (Merz, et al., 2007).

GIS and Remote sensing techniques

Geographic Information system (GIS) is computer based system that provides capabilities for input, data management, data storage and retrieval, manipulation, 
analysis and output to handle spatial data (Aronoff, 1995; Bhatt,et al., 1995). GIS technology is essential in the hazard and flood related problems which support surface water modeling and flood hazard exposure (Boyle et al, 1998; Greene \& Cruise, 1995; Paudyal). GIS and remote sensing focus on delineation of flood zones, preparation of flood hazard and risk maps (Bhatt, et al., 2013). According to Gashaw and Legesse (2011), Flood hazard mapping is a vital component for mitigation and appropriate land use planning in flood prone areas. It creates easily read, rapidly accessible charts and maps, which facilitates the administrators and planners to identify areas of risk and prioritize their mitigation/response efforts.

Remote sensing has substantial contribution in flood monitoring and damage assessment. Flood monitoring using satellite data provides an effective method to get quick and precise overview of flooded areas. High resolution imagery and digital elevation model (DEM) can be used in ArcGIS to develop flood prone areas (Jeyaseelan, 2004; Kussul, et al., 2008). DEM can be used to show areas of different vulnerability to flood hazard. A flow accumulation models can be used in the DEM and the DEM can be reclassified into high risk, moderate risk and low risk zones using equal interval of separation based on elevation (Lillesand, et al., 2004; Forkuo, 2008; Forkuo, 2010). Panchromatic satellite image data can be used for flood hazard assessment with the help of various digital image processing techniques, such as, image to image registration, texture analysis, Edgesharpening filter and image classification methods(Wang, 2004; Jain et al., 2005).

Demirkesenet al., (2006) observed that delineating flood extent areas and water bodies are always the most important concern to deal with flood mapping process. LANDSAT images are typically the primary preference because of their convenient obtainment. LANDSAT, SRTM, ASTER DEM is known as an economical and efficient method for mapping flood hazard and deal with the problem of inadequate data source in developing countries (Wang, 2004). A combination of GIS extension, DEM and HECRAS model can be used to delineate floodplain and visualizing the spatial extent of different flood scenarios and determining flooded areas at risk (Yang, et al., 2006).

Remote sensing and GIS pay vital role in flood vulnerability assessment of human settlements. GIS and remote sensing techniques help in the identification of locations of high grounds during the extreme hydrological events. It also helps to identify the settlements fall in a zone that is expected to experience a high flood discharge cause extraordinary damage to life and property (Cannon, 2000).
High resolution satellite imageries can be used to study to classify non flooded areas and flooded zones and to delineate human settlement at village level. GIS and remote sensing techniques are cost effective and efficient way to create a moderate resolution database for identifying human settlement that are highly vulnerable to flooding (Henderson and Xia, 1997).

Flash Flood Risk Assessment

Flash floods are floods that rise and fall rapidly with little or no advance warning. Flash floods are common in mountainous regions of Karakoram, Himalayaand HinduKush. They are usually caused by intense rainfall or a sudden, outburst of a landslide dam or glacier lake or by failure of artificial hydraulic structures (Bahadurzai and Shrestha, 2008; ICIMOD, 2011). Flash flood risk assessment is essential in making decisions and in the management of flood risk. Flash flood risk assessment has four steps such as characterizing the area, determining hazard level and intensity, assessing vulnerability and assessing risk. Characterizing an area prone to flash floods is important for hazard and vulnerability assessment, some important information's are, geography, geology and geomorphology, hydrology and hydraulics, vegetation, land use and historical analysis (Borga, et al., 2014;Shrestha, 2005). Hazard analysis includes defining the strength of the flash flood and scenarios in the area where it will occur. Assessing physical and socio-economic vulnerability is an important step in flash flood risk assessment. Physical vulnerability includes susceptibility and exposure while socio-economic vulnerability based on quantitative and qualitative indicators. Assessing hazard and vulnerability has four levels (High, moderate, moderately low and low. Four levels of hazards and four levels of total vulnerability are considered as risk level scale which can be classified into five different risk levels: very high, high, moderate, moderately low and low (Bahadurzai and Shrestha, 2008; Cutter, 1996).

Global Warming and Flood risk in Mountainous Areas

Climate change has been suggested to be a cause for increasing losses from extreme weather events (IPCC, 2007).Climate change and global warming have been progressively more under media scrutiny over the past 20 years.During this period, the concerns over global warming and climate change issues have gradually shifted froma mainly scientific concern to mainstream media (Singh and Kumar, 1997). In 1990, the IPCC confirmed the increase of greenhouse gasses in the atmosphere and the resulting global warming of the earth. 
Flooding caused by extensive and long-lasting rainfalls, partly connected with the melting of snow and ice, occurs mostly in plain areas. Local, sudden floods/flash flooding in small catchments that is mainly caused by short and highly intensive precipitation/ thunderstorms. Flash floods occur primarily in hill and mountainous areas due to prevailing convective rainfall mechanisms(Allmano, et al., 2009; Mokrech, et al., 2008). The mean global temperature has risen by $0.3-0.6 \mathrm{C}^{\mathrm{o}}$ since the end of the $19^{\text {th }}$ century, and $0.2-0.3 \mathrm{C}^{\mathrm{o}}$ of this increase occurred in the last 40 years (Feyen, et al., 2009).In mountainous regions temperature determines the situation of precipitation and in turn considerablyaffects runoff formation. The seasonalityof streamflow in mountainous basins has been found to be exceptionally sensitive to global warming (Diaz et al., 2003; Barnett et al., 2005; Bates et al., 2008; Marty, 2008). While the anxiety about the increase of flood risk in theseareas is rapidly raising (Olsen et al., 1998; Palmer andRalsanen, 2002). In the scientific literature there is still a lack of consensus about the effects of temperature variationson floods (Mudelsee et al., 2003; Birsan et al., 2005).

Klien and Konnen (2003) analyzing peak discharge timeseries recorded in different gauging stations in the Swiss Alps found significant increase of flood peaks during the last century. The impacts of an intensification of the hydrological cycle, most notably in connection with the possibility of an increasing occurrence of extreme events are also important to the millions of people living downstream of mountain river basins. The HinduKush, Karakoram and Himalayan $(\mathrm{HKH})$ region is extremely vulnerable to various types of water-induced disasters, particularly floods and landslides (ICIMOD, 2010). A significant increase in heavy rainfall events in future will result in an increased flood risk to society, physical infrastructure, and water quality. Increases in the frequency and severity of floods and droughts are projected to have an adverse effect on sustainable development. Shrestha et al (2003) suggest that the number of flood days and consecutive days of flood events have been increasing in mountainous regions of South Asia. Increases in glacial melting and likely increases in runoff will also intensify the risk of glacial lake outburst floods.Unpredictable precipitation and increased glacial melting might aggravate the flooding that is already common in mountain areas such as riverine floods, flash floods, glacial lake outburst floods, and breached landslide dams(Bajracharya, et al., 2007; ICIMOD, 2009; Shrestha, 2009).
Flood early warning systems is important in mountainous regions which include a chain of activities: understanding and mapping flood vulnerability,monitoring rainfall and water levels, forecasting impending events, processing, and disseminating andcommunicating understandable warnings to decision makers and the population so that they can take appropriate and timely actions in response (UNISDR 2007, IUCN, 2009).

Flood Risk Management

Floods are one of the most common hazards in the world, affecting people's lives and livelihoods (Uddin, et al., 2013). Flood hazard management epitomize the multidimensional nature of much environmental management. It is a problem integrates aspects of the natural sciences, the social sciences, and engineering. It is significant for the efficiency and efficacy of the decision making process to recognize the complexity (Penning, 1996). Flood risk management is an organized process of using administrative directives, organizations, and operational skills and capacities to implement strategies, policies, and improved coping capacities in order to lessen the adverse impacts of flood hazard and the possibility of disaster (Mitchell, et al., 2010). The term management is used in at least two different ways in the literature on floods, either excluding or including risk analysis. The first understanding is based on the hydrological reliability of existing flood defense structures. Management is interpreted, therefore, as decisions and actions undertaken to mitigate the remaining risk above flood protection design standards (Hooijer et al., 2004; Oumeraci, 2004). The second understanding defines management as decisions and actions undertaken to management covers the risk analysis, risk assessment and risk reduction (Plate 1999, Sayers et al., 2002, Hall et al., 2003).

For a comprehensive approach, UNDRO (1991) has identified four tasks and components: Risk analysis, Risk assessment and Risk reduction. Risk analysis provides information on previous, current and future flood risks, risk assessment deals with their perception and evaluation and risk reduction is dedicated to interventions with a potential to decrease the risks. Flood analysis included; hazard determination, vulnerability determination and risk determination. Risk assessment included; risk perception and risk weighting. Risk reduction is based on pre-flood reduction, flood event reduction and preinterventions(Correia, et al., 1997). The concept of flood risk management now is an activity of several professional communities: hydrologist, engineering, economist, social scientist, environmentalist, ecologist and planners. The 
concepts used in these professions and between them internationally do not share a common terminology; thus there is a need to develop coordination among these professions for accepted disaster management language (NCR, 2002). Community based flood warning systems can go a long way inhelping communities, as well as flood management agencies, to prepare for flash floods.The enhancement of community resilience through socioeconomic empowerment and strengthened adaptive capacity can pay a vital role in flood disaster management (Deka, 2008; Goswami, 1998, Hazarika, 2010).

\section{CONCLUSION}

In this paper, we have reviewed and synthesized concepts and techniques of flood hazard, vulnerability and risk assessment into a coherent piece and give an overview of recent literature related to flood risk assessment. Floods are the most lethal kind of hydro-meteorological disaster on the earth surface.Flooding is the most common of all environmental hazards and it regularly claims over huge number of lives per year and adversely affects around millions of the people world-wide.More than one third of the world's land area is flood prone which affecting around 82 percent of the world population. Using PRISMA methodology of literature review, 120 articles were retrieved using Pub med and Google Scholar database. 90 articles were included in the initial review. 30 articles were excluded from the review after reading the whole content because they did not match the objectives of the literature review and the inclusion criteria. Meteorologically flood can be defined as situation over a region or place where that rainfall is mostly heavy and higher than the normal climatological mean value.GIS and remote sensing play an important role in flood hazard, vulnerability and in risk assessment and useful for delineation of flood zones, preparation of flood hazard and risk maps

Flood risk is a function and a product of hazard and vulnerability. Flood Hazard assessment is based flood probability scenarios in the areas where it will hit and strength of the flood. Assessing vulnerability based on physical and socioeconomic processes. Assessing physical vulnerability depends on the susceptibility and exposure to hazards. An exposure indicator depends on how far the receptor is from the source of the hazard. Exposure can be described as high, moderately high, moderate, and low, which constitutes a qualitative description of levels of exposure. Susceptibility to floods is the state of defenselessness, whereas high susceptibility, has the potential to endanger or lose lives, property, ecological species, and landscapes. Assessing socioeconomic vulnerability based on the adaptive capacity of a society and status of economic activities or it is a combination of qualitative and quantitative indicators.Four levels of hazard and four levels of total vulnerability (high, moderate, moderately low and low) can be used in risk assessment. Risk level scale can be categorizedinto five different risk levels, such as very high, high, moderate, moderately low and low. A significant increase in heavy rainfall events in the future will result in an increased flood risk to society, physical infrastructure, and water quality. The enhancement of community resilience through socioeconomic empowerment and strengthened adaptive capacity can play a vital role in flood disaster management.

\section{REFERENCES}

[1] Ghimire, M (2010). Landslide occurrence and its relation with terrain factors in the Siwalik Hill, Nepal: Case study of susceptibility assessment in three basins. Natural Hazards. 56, 299-320.doi 10.1007/s11069-0109569-7.

[2] Harma, A.P. (2013). Climate Change adaptation, disaster risk reduction and livelihood -based social protection. NGO Network Bulletin on Climate Change, Issue 5, September 2013, LI-BRID, Pokhara.

[3] Burton, I., Kates, R.W., and White, G.F. (1978). The environment as hazard. Oxford University Press, New York, NY.

[4] ADPC. (2015). Course material under capacity building in Asia using information technology applications. CASITA project, Asia Disaster Preparedness Center (ADPC), Bankok. Retrieved March 21, 2015 from http://www. Adpc.net/casita/course-material/Mod-2-hazard.pdf.

[5] Bohle, H.G. (2001). Vulnerability and criticality: Perspective from social Geography. IHDP update 2/2001, 1-7.

[6] UNISDR. (2009) Terminology on disaster risk reduction. United Nations International Strategy for Disaster Reduction, Geneva, Switzerland. Retrieved December 20, 2015 from unisdr.org/eng/library/lipterminology-eng.htm.

[7] Blaikie, P., Cannon, T., Davis, I., and Wisner, B. (1994). At Risk: Natural hazard, people, vulnerability, and disasters. Routledge, London, UK.

[8] Ologunorisa, E. T. (2004).An Assessment of Flood Vulnerability Zones in the Niger Delta, Nigeria. 
International Journal of Environmental Studies, U. K. Vol. 61, No. 1

[9] Khan, A.N., Rahman, A.U., (2005). An Assessment of Flood Hazard Causes for Efficient Flood Plain Management: A Case of Neelum -Jhelum Valley, Muzaffarabad, A.J.K. Pakistan Geographic Review.Vol 60, No1, 2005, pp 42-53.

[10] Borga, M., Stoffel, M., Marchi, L., Marra, F., Jakob, M., 2014. Hydrogeomorphic response to extreme rainfall in headwater systems: flash floods and debris flows. J. Hydrol. http://dx.doi.org/10.1016/j.jhydrol.2014.05.022.

[11] Wheater, H. and Evansb, E.,(2009)"Land use, water management and future flood risk", Land Use Policy. 1:S251-S264.

[12] Delley M, Chen RS, Deichmann U, Lerner-Lam AL, Arnold M with Awe J, Buys P Kjekstad O, Lyon B, Yetman G (2005). Natural Disaster hotspots: a global risk analysis. International Bank for Reconstruction and Development /The World Bank and Columbia University, Washington, DC.

[13] United National Development Programme-UNDP, (2004). Reducing disaster risk: A challenge for development. United Nations Development Programme, Bureau for Crisis Prevention and recovery, New York, $146 \mathrm{pp}$.

[14] ICIMOD, (2002). Hazard and RISK Mapping (Internal Report). Kathmandu: Participatory Disaster Management Programme (Nep 99/014) and ICIMOD.

[15] llamano, P., P. Claps, and F. Laio (2009), Global warming increases flood risk in mountainous areas, Geophys. Res. Lett., 36, L24404, doi:10.1029/2009GL041395.

[16] Diaz, H., J. Eischeid, C. Duncan, and R. Bradley (2003), Variability of freezing levels, melting season indicators, and snow cover for selected highelevation

[17] Barnett, T., J. Adam, and D. Lettenmaier (2005), Potential impacts of a warming climate on water availability in snow-dominated regions, Nature, 438, 303-309, doi:10.1038/nature04141.

[18] Bates, B., Z. Kundzewicz, S. Wu, and J. Palutikof (Eds.) (2008), Observed and projected changes in climate as they relate to water, in Climate Change and Water, IPCC Tech. Pap. VI, pp. 13-31, Intergov. Panel on Clim. Change Secr., Geneva, Switzerland.
[19] Marty, C. (2008), Regime shift of snow days in Switzerland, Geophys. Res. Lett., 35, L12501, doi: 10.1029/2008GL033998.

[20] Smith, K. (1996) Environmental Hazards. London: Routledge.

[21] Adger, W.M., (2006). Vulnerability. Global Environmental Change. Tyndall Center for Climate Change Research, School of Environmental Sciences, university of East Anglia, Norwich, 16, pp, 268-281.

[22] Proag, V., (2014). The concept of vulnerability and resilience. $4^{\text {th }}$ international conference on Building Resilience, Building Resilience. Procedia Economic and Finance 18, pp, 369-376.

[23] Cutter S.L., 1996. Vulnerability to environmental hazards; Progress in Human Geography 20(4) 529. 539.

[24] Cutter S.L., Boruff B.J., Shirley W.L., 2003. Social vulnerability to environmental hazards. Soc Sci $Q$ 84(2):242-261

[25] Smith K. and Petley D.N., (2009). Environmental hazard, Accessing risk and reducing disaster. Fifth edition.British Library. ISBN 10: 0-203-88480-9.

[26] Solı'n L' (2012) Spatial variability in the flood vulnerability of urban areas in the headwater basins of Slovakia. J Flood Risk Manag 5:303-320

[27] Solı'n L', Feranec J, Nova'c`ek J (2011) Land cover changes in small catchments in Slovakia during 1990-2006 and their effects on frequency of flood events. Nat Hazards 56:195-214.

[28] Tsay, Lin (2013) Flooding Vulnerability Assessment - A Case Study of Hou-Jing Stream in Taiwan. Mediterranean J Social Sci.

[29] Forkuo, Eric K (2011) Flood Hazard Mapping using Aster Image data with GIS. Int J Geomat Geosci.

[30] Getahun YS, Gebre SL (2015) Flood Hazard Assessment and Mapping of Flood Inundation Area of the Awash River Basin in Ethiopia using GIS and HEC-GeoRAS/HEC-RAS Model. J Civil Environ Eng 5: 179. doi:10.4172/2165-784X.1000179

[31] Pradhan, B., Pirasteh, S., Shafie, M., 2009. Maximum flood prone area mapping using RADARSAT images and GIS: Kelantan river basin. International Journal of Geoinformatics 5 (2), 11-23.

[32] Askew, A. J. (1999) Water in the International Decade for Natural Disaster Reduction. In Leavesley et al (eds) Destructive Water: Water-caused Natural Disasters, their Abatement and Control. IAHS. Publication No. 239. 
[33] Ologunorisa, E. T. (2001) An Assessment of Flood Risk in the Niger Delta, Nigeria. Unpublished Ph. D. Thesis, University of Port-Harcourt, Nigeria 303pp.

[34] Sayeeda A. Sayed, Pedro Arcos González. Flood Disaster Profile of Pakistan: A Review. Science Journal of Public Health. Vol. 2, No. 3, 2014, pp. 144-149. doi: 10.11648/j.sjph.20140203.1.

[35] UNCHS, (1981) Settlement Planning for Disasters, Nairobi, World Meteorological Organization (W.M.O) (1975) Drought and Agriculture.

[36] Parthasarathy, B. Sontakke, N. A; Monot, A. A. and Kothawale, D. R. (1987) Droughts/Floods in the Summer Monsoon Season Over different Meteorological Sub-divisions of India for the Period 1871-1982. Journal of Climatology, Vol. 7, pp. 5770.

[37] Ali AMS (2007) September 2004 flood event in Southwestern Bangladesh: a study of its nature, causes, and human perception and adjustments to a new hazard. Nat Hazards 40:89-111

[38] Atta-ur-Rahman (2003) Effectiveness of flood hazard reduction policies: a case study of KabulSwat floodplain, Peshawar vale. MPhil thesis, submitted to the Department of Geography, Urban and regional Planning, University of Peshawar

[39] Atta-ur-Rahman (2010) Disaster risk management: flood perspective. VDM Verlag, Germany

[40] Atta-ur-Rahman, Khan AN (2010) Causes and environmental impacts of flood hazard: a case study of sample villages, Swat valley, Pakistan. In: Proceedings of the 4th international congress of the Islamic world geographers (ICIWG 2010) Iran, 1416 April 2010, pp 161-180

[41] Atta-ur-Rahman, Khan AN, Collins AE, Qazi F (2011) Causes and extent of environmental impacts of landslide hazard in the Himalayan region: a case study of Murree, Pakistan. Nat Hazards 57(2):413434

[42] Mirza MMQ (2003) Three recent extreme floods in Bangladesh: a hydro-meteorological analysis. Nat Hazards 28(1):35-64

[43] Hayden, B. P. (1988) Flood Climates. In Baker et al (eds) Flood Geomorphology. New York: John Willey and Sons.

[44] Trinic, D. (1997) Hydrological Analysis of High Flows and Floods in the Sava River near Zagreb, Croatia, IAHS Publications No. 239, pp.51-58.

[45] Nobilis, F. and Lorenz, P. (1997) Flood Trends in Australia. IAHS Publication No. 239, pp. 77-81.
[46] Smakhtin, V.U., 2001. Low flow Hydrology: a review. Journal of Hydrology. pp 147-186.

[47] Menzel, L., Niehoff, D., Burgeer, G., and Brinstert, A. (2002). Climate change impacts on river flooding: A modeling study of three meso-scale catchments. In M. Beniston (Ed.), Climatic change: implications for the hydrological cycle and for water management. Advances in global change research, pp, 249-269.

[48] Koutsoyiannis, D., A. Montanari, H. Lins, and T. Cohn (2009), Discussion of: The implications of projected climate change for freshwater resources and their management, Hydrol. Sci. J. Sci. Hydrol., 54, 394- 405 .

[49] Gunderson LH, Holling CS. 2001. Panarchy: Understanding Transformation in Human and Natural Systems. Washington,DC: Island.

[50] Janssen, M.A., Schoon, M.L., Ke, W., Bo“ rner, K., 2006. Scholarly networks on resilience, vulnerability and adaptation within the human dimensions of global environmental change. Global Environmental Change 16 (3), 240-252.

[51] Adger, W.N., Winkels, A., 2006. Vulnerability, poverty, and sustaining well-being. In: Atkinson, G., Dietz, S., Neumayer, E. (Eds.), Handbook of Sustainable Development. Elgar, Cheltenham.

[52] Adger, W.N., Arnell, N.W., Tompkins, E.L., 2005a. Successful adaptation to climate change across scales. Global Environmental Change 15, 77-86.

[53] Colombo, AG, Hevas, J; Arllam, ALV (2002) Guidelines on flash floods prevention and mitigations. Ispra (VA) Italy: NEIDES

[54] Cutter, SL (1996) Vulnerability to natural hazards. Progress in Human Geography, 20, pp529-539. Available at sagejournalsonline, http://phg.sagepub.com/current_dtl

[55] Gouldby, B; Samuals, P (2005) Language of risk, wallingford, flood site. Oxfordshire (UK): Floodsite project, Floodsite Consortium

[56] Messner, F; Meyer, V (2005) Flood damage, vulnerability and risk perceptions - challenge for flood damage research, Leipzig, UFZUmweltforschungszentrum Leipzif-halle: Helmholtz Centre for Environmental Research

[57] ICIMOD (2007) Inventory of Glaciers, Glacial Lakes, and Identification of Potential Glacial Lake Outburst Flood (GLOFs) Affected by Global Warming in the Mountains of Himalayan Region. Kathmandu: ICIMOD. 
[58] ICIMOD (2008). Resource Manual onFlash Flood Risk Management Module, Non-structural Measures.Kathmandu: ICIMOD.

[59] Birkmann J (2007) Risk and vulnerability indicators at different scales: applicability, usefulness and policy implications. Environ Hazards 7(1):20-31

[60] Chen, W. L. (2010). Assessing Land Use Flood Control Measures Based on Flood Risk Management Approach--A Case of Yanshuei River Basin, Taiwan

[61] Tung, C. P. (2011). Investigation on Analysis Method of Flood Vulnerability and Risk Maps

[62] Ali, K., Begum, F., Ali, B., Abbas, Q., (2015). Psychological effects of 2010 Attaabad landslide on upstream communities of upper Hunza, district Hunza - Nagar, Pakistan. Journal of Biodiversity and Environmental Sciences., pp, 2222-3045, Vol. 6, No. 3, p. 54-64. http://www.innspub.net.

[63] Rose, A. (2007). Economic Resilience to Natural and Man-Made Disasters; Multidisciplinary Origins and Contextual Dimensions. Environmental Hazards 7(4), 383-398.

[64] Cutter, S. L., B. Boruff, and W. L. Shirley. 2001. "Indicators of Social Vulnerability to Hazards." Unpublished paper. Columbia, S.C.: University of South Carolina, Hazards Research Lab.

[65] Merz, B., Thieken, A.H. and Gocht, M, (2007) Flood Risk Mapping at the Local Scale: Concepts and Challenges in Flood Risk Management in Europe", Springer Netherlands, pp. 231-251.

[66] Aronoff, S., (1995). "Geographic Information Systems: A Management Perspective”, WDL Publications, Ottawa.

[67] Bhatt, G.D., Kushwaha, S.P.S., Nandy, S., Bargali, K., Nagar, P.S., and Tadvi, D.M., (2013). "Analysis of forest fragmentation and disturbance regimes in south Gujarat forests using geospatial technology", Tropical Ecology, Vol. 56(3).

[68] Bhatt, G.D., Kushwaha, S.P.S., Nandy, S. and Bargali, Kiran., (2013). "Vegetation types and land uses mapping in south Gujarat using remote sensing and geographic information system", International Journal of Advancement in Remote Sensing, GIS and Geography, Vol.1, No.1, 20-31.

[69] Gashaw, W., and Legesse, D., (2011). Flood hazard and Risk assessment Using GIS and Remote Sensing in Fogera Woreda, Northwest Ethiopia.

[70] Boyle, S. J., Tsanis, I. K. \& Kanaroglou, P. S. (1998) Developing geographic information systems for land use impact assessment in flooding condition. J. Wat. Resour. Plan. Manage., ASCE 124(2), 89-98.

[71] Greene, R. G. \& Cruise, J. F. (1995) Urban watershed modelling using geographic information system. /. Wat. Resour. Plan. Manage., ASCE 121(4), 318-325.

[72] Paudyal, G. N. (1996) An integrated GIS-numerical modelling system for advanced flood management. In: Proc. Int.Conf. on Water Resources \& Environment Research: Towards the 21st Century (Kyoto University, Japan), 555-562, Water Resource Research center, Tyoto uni,,Tyoto, Japan

[73] Jeyaseelan, A.T., 2004. Droughts \& floods assessment and monitoring using Remote Sensing and GIS. Satellite Remote Sensing and GIS Applications in Agricultural Meteorology, 291-313.

[74] Kussul, Natalia, Shelestov, Andrii, Skakun, Serhiy, Kravchenko, Oleksii, 2008. Data assimilation technique for flood monitoring and prediction. International Journal Information Theories \& Applications 15, 76-83.

[75] Lillesand, M. Thomas and W. Ralph Kiefer (2004) Remote Sensing and image Interpretation: $5^{\text {th }}$ ed. John Wiley \& Sons, Inc.

[76] Forkuo, E. K., 2008. "Digital Terrain Modeling in a GIS Environment". The International Archives of Photogrammetry, Remote Sensing and Spatial Information Sciences, 37(B2), pp 1023-1029.

[77] Forkuo, E. K., 2010. "Digital Elevation Modeling Using ASTER Stereo Imagery", Journal of Environmental Science and Engineering, 52(2), pp 81-92.

[78] Wang, Y., 2004. Using Landsat 7 TM data acquired days after a flood extent on a coastal floodplain. International Journal of Remote Sensing, 25: 5, p959 $-974$.

[79] Jain, S.K., Singh, R. D., Jain, M. K. and Lohani, A. K., 2005. Delineation of Flood-Prone Areas Using Remote Sensing Techniques, Journal of Water Resources Management,Springer 2005, 19: 333347.

[80] Demirkesen, A.C., Evrendilek, F., Berberoglu, S., and Kilic, S., 2006. Coastal Flood Risk Analysis Using Landsat-7 ETM+ Imagery and SRTM DEM: A Case Study of Izmir, Turkey. Environmental Monitoring and Assessment (2007) 131:293-300, Springer Science + Business Media B.V. 2006.

[81] Wang, Y., 2004. Using Landsat 7 TM data acquired days after a flood extent on a coastal floodplain. 
International Journal ofRemote Sensing, 25: 5, p959 $-974$.

[82] Yang J, Townsend RD, Daneshfar B (2006). Applying the HEC-RAS model and GIS techniques in river network floodplain delineation. Canadian. J. Civil. Eng. 33(1): 19-28.

[83] CannonT.2000.Vulnerabilityanalysisanddisasters.InF loodsVolI,ParkerDJ(ed.).Routledge:NewYork;45-55.

[84] Henderson FM, Xia ZG. 1997. SAR applications in human settlement detection, population estimation and urban land use pattern analysis: a status report. IEEE Transactions on Geoscience and Remote Sensing 35(1): 79-85.

[85] Azizi, PM; Naimi, Q (2006). Status report of flash flood events and mitigation management in Afghanistan in $\mathrm{Xu}, \mathrm{J}$; Eriksson, M; Ferdinand, J; Merz, J (Ed) 'Managing flash floods and sustainable development in the Himalayas', proceedings of the International workshop on flash floods management and sustainable development held in Lhasa, Tibet in October 2005 pp. 81

[86] Shrestha, A (2005) Vulnerability assessment of weather disasters in Syangja District, Nepal: A case study of Putalibazar Municipality, advanced institute on vulnerability to global environmental dhange/global change system for analysis research and training. Kathmandu: START and Department of Hydrology, Nepal

[87] Colombo, AG, Hevas, J; Arllam, ALV (2002) Guidelines on flash floods prevention and mitigations. Ispra (VA) Italy: NEIDES

[88] Cutter, SL (1996) Vulnerability to natural hazards. Progress in Human Geography, 20, pp,529-539. Available at sagejournalsonline, http://phg.sagepub.com/current_dtl

[89] Gouldby, B; Samuals, P (2005) Language of risk, wallingford, flood site. Oxfordshire (UK): Floodsite project, Floodsite Consortiu

[90] Messner, F; Meyer, V (2005) Flood damage, vulnerability and risk perceptions - challenge for flood damage research, Leipzig, UFZUmweltforschungszentrum Leipzif-halle: Helmholtz Centre for Environmental Research

[91] Meybeck, M., Green, P., and Vörösmarty, C.: 2001, 'A New Typology forMountains and other Relief Classes: An Application to Global Continental Water Resources and Population Distribution', Mount. Res. Dev. 21, 34-45.
[92] Singh P, Kumar N. 1997. Impact assessment of climate change on the hydrological response of a snow and glacier melt runoff dominated Himalayan river. Journal of Hydrology 193: 316-350.

[93] Mokrech, M., Nicholls, R.J., Richards, J.A., Henriques, C., Holman, I.P., Shackley, S., 2008. Regional impact assessment of flooding under future climate and socioeconomic scenarios for East Anglia and North West England. Climatic Change 90, 3155.

[94] Feyen, L., Barredo, J.I., Dankers, R., 2009. Implications of global warming and urban land-use change on flooding in Europe. In: Feyen, J., Shannon, K., Neville, M. (Eds.), Water and Urban Development Paradigms. Taylor and Francis, pp. 217-225.

[95] Diaz, H., J. Eischeid, C. Duncan, and R. Bradley (2003), Variability of freezing levels, melting season indicators, and snow cover for selected highelevation and continental regions in the last 50 years, Clim. Change, 59, 33- 52.

[96] Barnett, T., J. Adam, and D. Lettenmaier (2005), Potential impacts of a warming climate on water availability in snow-dominated regions, Nature, 438, 303-309, doi:10.1038/nature04141.

[97] Bates, B., Z. Kundzewicz, S. Wu, and J. Palutikof (Eds.) (2008), Observed and projected changes in climate as they relate to water, in Climate Change and Water, IPCC Tech. Pap. VI, pp. 13-31, Intergov. Panel on Clim. Change Secr., Geneva, Switzerland.

[98] Marty, C. (2008), Regime shift of snow days in Switzerland, Geophys. Res. Lett., 35, L12501, doi:10.1029/2008GL033998.

[99] Olsen, R., J. Lambert, and Y. Haimes (1998), Risk of extreme events under nonstationary conditions, Risk Anal., 18, 497- 510.

[100] Palmer, T., and J. Ralsanen (2002), Quantifying the risk of extreme seasonal precipitation events in a changing climate, Nature, 415, 512- 514.

[101] Mudelsee, M., M. Bo“rngen, G. Tetzlaff, and U. Gru"newald (2003), No upward trends in the occurrence of extreme floods in central Europe, Nature, 425, 166- 169. Birsan, M., P. Molnar, P. Burlando, and M. Pfaundler (2005), Streamflow trends in Switzerland, J. Hydrol., 314, 312- 329.

[102] Klein Tank, A., and G. Ko“nnen (2003), Trends in indices of daily temperature and precipitation 
extremes in Europe, 1946-99, J. Clim., 16, 36653680 .

[103] ICIMOD (2010a) Global climate financing mechanisms and mountain systems. Working paper prepared for the Mountain Initiative of the Government of Nepal. Kathmandu, Nepal.

[104] ICIMOD (2009b) Biodiversity and climate change in the Himalayas: Sustainable mountain development, Newsletter No 55 Spring. Kathmandu, Nepal.

[105] Bajracharya, SR; Mool, PK; Shrestha, BR (2007) Impact of glaciers and on Himalayan glaciers and glacial lakes: Case studieson GLOF and associated hazards in Nepal and Bhutan. Kathmandu, Nepal: ICIMOD

[106] Bajracharya, SR; Shrestha, B (2011) The status of glaciers in the Hindu Kush-Himalayan region. Kathmandu, Nepal: ICIMOD

[107] Shrestha, RR (2009b) 'Rainwater harvesting and groundwater recharge for water storage in the Kathmandu Valley.' ICIMOD Newsletter 56: 27-30

[108] Shrestha, AB (2009a) 'Climate Change in the Hindu Kush-Himalayas and its impacts on water and hazards.' APMN (Asia Pacific Mountain Network) Bulletin 9: 1-5

[109] Singh, DK; Singh, AK (2002) 'Groundwater situation in India: Problems and perspective.' International Journal of Water Resources Development 18(4): 563-580

[110] UNISDR (2007) Gender perspective: Working together for disaster risk reduction: Building the resilience of nations and communities to disasters. Geneva, Switzerland: United Nations Inter-Agency Secretariat of the International Strategy for DisasterReduction

[111] UNISDR (no date) Basics of early warning. [online] International Strategy for Disaster Reduction, Platform for the Promotion of Early Warning. www.unisdr.org/2006/ppew/whats-ew/basicsew.htm (accessed 7 July 2014)

[112] UNISDR; UNDP; IUCN (2009) Making disaster risk reduction gender sensitive: policy and practical guidelines. Geneva, Switzerland: UNISDR, UNDP and

IUCN www.preventionweb.net/files/9922_MakingDisaster RiskReductionGenderSe.pdf

[113] Uddin, K., Gurung, D.R., Giriraj, A., Shrestha.,(2013). Application of Remote Sensing and GIS for Flood Hazard Management: A Case Study from Sindh Province, Pakistan. American
Journal of Geographic Information System, 2 (1); 15.

[114] Penning-Rowsell, E. (ed.): 1996, Improving Flood Hazard Management Across Europe, Middlesexm University Press, London.

[115] Mitchell, T., Ibrahim, M., Harris, K., Hedger, M., Polack, E., Ahmed, A., Hall, N., Nawrylyshyn, K., Nightingle, K., Onyango, M., Adow, M., and Mohammed, S. (2010). Climate Smart Disaster Risk Management Strengthening Climate Resilience, Brighton: IDS.

[116] Correia, F. N., Saraiva, M. G. and Silva, F. N., (1997), Floodplain Management in Urban Developing Areas, submitted to publication in Water Resour. Manage., Kluwer Academic Publishers, Dordrecht, the Netherlands.

[117] Deka, CR (2008) Land degradation by Jiadhal River of Dhemaji District: A study using remote sensing and GIS technique. ENVIS Assam Newsletter (October-December 2008 ): $\quad 2, \quad 8$. www.envisassam.nic.in/newsletter/08\%20 4octdec.pdf (accessed 1 December 2011)

[118] Goswami, DC (1998) 'Fluvial regime and flood hydrology of the Brahmaputra River, Assam.' Memoir Geological Society of India 41: 53-75

[119] Hazarika, UM (2003) Problems of flood, erosion and sedimentation in the Jiadhal River basin, Dhemaji District, Assam: A geo-environmental study. $\mathrm{PhD}$ thesis, Gauhati University, Guwahati, Assam, India

[120] Hazarika, UM (2010) 'Fluvial environment of Jiadhal River basin, Dhemaji District, Assam.' International Journal of Ecology and Environmental Sciences 36(4): 271-275.

[121] Shrestha, AB (2008) Resource manual on flash flood risk management: Module 2 - Non- structural measures. Kathmandu, Nepal: ICIMOD

[122] Shrestha, AB; GC, E; Adhikary, RP; Rai, SK (2012) Resource manual on flash flood risk management Module 3: Structural measures. Kathmandu, Nepal: ICIMOD

[123] Shrestha, AB; Shah, SH; Karim, R (2008) Resource manual on flash flood risk management: Module 1 Community basedmanagement. Kathmandu, Nepal: ICIMOD

[124] Allmano, P., P. Claps, and F. Laio., (2009). Global warming increases flood risk in mountainous areas, Geophys. Res Lett., 36 L24404,10.1029/2009GL041395. 
[125] Madhuri, Tewari, H.R. \& Bhowmick, P.K., 2014,

'Livelihood vulnerability index analysis: An approach to study vulnerability in the context of Bihar', Jàmbá: Journal of Disaster Risk Studies 6(1), Art. \#127, 13 pages. http://dx.doi. org/10.4102/jamba.v6i1.127

[126] Gerlitz, J; Banerjee, S; Hoermann, B; Hunzai, K; Macchi, M, and Tuladhar, S (2014) Poverty and vulnerability assessment - A survey instrument for the Hindu Kush Himalayas. Kathmandu: ICIMOD 